University for Business and Technology in Kosovo

UBT Knowledge Center

UBT International Conference

2012 UBT International Conference

Nov 2nd, 9:00 AM - Nov 3rd, 5:00 PM

\title{
Managing and Minimizing Waste Generation During Construction: Approaches and Responsible
}

Krenare Shkodra

University for Business and Technology

Follow this and additional works at: https://knowledgecenter.ubt-uni.net/conference

Part of the Architecture Commons

\section{Recommended Citation}

Shkodra, Krenare, "Managing and Minimizing Waste Generation During Construction: Approaches and Responsible" (2012). UBT International Conference. 19.

https://knowledgecenter.ubt-uni.net/conference/2012/all-events/19

This Event is brought to you for free and open access by the Publication and Journals at UBT Knowledge Center. It has been accepted for inclusion in UBT International Conference by an authorized administrator of UBT Knowledge Center. For more information, please contact knowledge.center@ubt-uni.net. 


\title{
Managing and minimizing waste generation during construction. Approaches and the Responsible.
}

\author{
Krenare Shkodra ${ }^{1}$ \\ ${ }^{1}$ Faculty of Architecture and Spatial Planning, University for Business and Technology, Kalabria n/n 10000 \\ Prishtina, Kosova
}

\begin{abstract}
Construction Waste is a well known and a serious threat to the environment therefore there are a number of existing approaches toward its management. It (construction waste) is considered recyclable up to $80-90 \%$, which is quite a promising factor especially giving the fact that recycling is only one of the steps in the construction waste management process along with reduce, reuse, and dispose. While taking this into consideration there is still doubt as to 'Why is Construction Waste still an issue to the environment? Does it get the required and deserved priority? If yes, by who and how?' While analyzing and comparing different models of construction waste management by different authors, this paper tries to find the main participants in this process as well as the main factors of its success or failure. This is done by studying articles on waste management and comparing these models in order to better understand their concept. Throughout analysis, this paper concludes quite a few similarities between these models, and moreover, their outcome seems to be induced by the same factors. Contractors, designers, clients and the government itself appear to be the main participants in the managing process, along with other factors. To improve the outcome of these models, proposals have been given, being mostly related to new legislation, regulation and policies. Whatever the difference and the outcome, these new legislation and policies might make, the approach of raising the awareness of the public and of the construction industry towards this issue turns out to be just as important.
\end{abstract}

Keywords: Construction; Waste; Management; Environment; Strategies; 


\section{Introduction}

A widely known and serious environmental threat seems to be the construction industry. This industry not only harvests most of the natural resources for its' needs, it also contributes to environmental degradation through the waste it generates, first during the production of the final materials (used for construction), and then after the actual construction has taken place. Construction waste is created due to factors and processes like: Transportation, Site storage, Conversion and cutting, Fixing, Application and residue, Uneconomic use of plant, Management, Wrong use, Wrongly specified materials, etc. (March, 2009, p. 124-126). As seen above, there are known factors or processes responsible for generating waste during construction but there needs to be a higher interest in lowering the percentage of this type of waste. Most of the waste generated during construction ends up in landfills, just like any other waste. However, construction waste has a higher possibility of being recy cled. According to Lauritzen (1998), 'in most European countries today, it is economically feasible to recycle 80-90\% of the total amount of construction waste'. So, we know what are some processes and factors of waste generation, we also know that this waste can somehow be managed and most of it (if generated) recycled. Now the question is WHO is responsible for this waste generation and WHO for its management? The 'who's' in this question range from the actual persons taking part in the construction, to the designers, construction companies, policy makers, manufacturing companies and waste collection companies. In this paper, there will be discussions and analysis of each participant's role in the generation and management of construction waste. In order to come up with an answer to the question in hand and find the ones 'responsible', this paper will first go through approaches used and how/why they worked or not in the construction waste management.

\section{How and why the construction industry initiates waste management?}

Waste generation is not only environmentally unacceptable but it is also costly. Due to concerns regarding the environmental protection and sustainable development, many countries are introducing new legislation and policy measures, which come in the form of higher landfill costs and taxes, lower taxes in using recycled materials (aggregate for example) and higher taxes in using virgin aggregate (Poon, 2007). On the other hand, construction waste management costs too. In waste management during construction, there is need, and of course additional cost, for managing waste separation (if planned for recycling) and waste disposal, and for monitoring if they are done correctly (March, 2009). To further increase these costs, construction companies have to invest in waste storage and recycling facilities (Poon, 2007). However, due to high landfill costs and taxes, which come as a result of ever decreasing landfill site space and environmental protection, the construction companies are pushed to take incentives towards investment in construction waste storage and recycling facilities (Poon, 2007). It is quite an apparent occurrence that construction companies' initiatives toward waste management is mostly cost driven. According to a study made by Tam (2008), also shown on the table below, construction companies' main goal during construction is to minimize cost. Cost minimization leads to construction companies being awarded projects. Even though implementing waste management programs (environmentally encouraged) helps achieving a long-term cost savings goal it also increases a short-time investment cost, which draws the construction industry from this type of initiatives and investments. In this case, the environmental factor has the least importance and plays almost no role in the construction industries' initiative toward construction waste management. This is also shown in the table below after a survey on project goal of construction projects and in construction waste management. According to the table below, the highest priority factor in projects is cost and the lowest priority goes to the environmental issues. This leads into believing that these two are more related than they would appear.

\begin{tabular}{|c|r|r|}
\hline $\begin{array}{l}\text { Project goal of construction } \\
\text { projects }\end{array}$ & Most important (\%) & \multicolumn{2}{|l|}{ Least important (\%) } \\
\hline Cost & 39.5 & 5.3 \\
\hline Time & 15.8 & 18.4 \\
\hline Quality & 18.4 & 15.8 \\
\hline Environmental & 0.00 & 47.4 \\
\hline Safety & 26.3 & 13.2 \\
\hline Total & 100.0 & 100.0 \\
\hline
\end{tabular}

Table 1 - Survey on project goal of construction projects and in construction waste management Source: Tam (2008) 
If the 'why' to our question meets 'cost' in the actual construction industry, then the 'how' should meet 'cost related legislation and policies'. In other words, according to the above information and data, the reason for waste management initiation would be cost related. This also means that one way of encouraging waste management to the construction industry is throughout legislation and policies, which would lead to economical benefit of the involved parties, therefore increase the environmental benefit as well. Some of the regulations might be for example higher landfill costs and taxes, also lower taxes on the use of some recycled materials and increasing them for some virgin materials which could easily be replaced with recycled materials. This is a point where the government, as a party which is pro construction waste management, plays a crucial role in its promotion by enforcing regulations for the whole construction industry (Karavezyris, 2007). For some cities the implementation of such regulations has actually been beneficial and the most important factor on waste management (Yuan, 2012a). However, according to Tam (2008) these regulations have shown limited effects in some economies, they have even reduced significantly the productivity of companies. Another addition to policies and legislation could be the demand for a construction waste management plan in the designing stage. This 'construction waste management plan' would show how does the designer or the construction company intent to reduce waste generation, starting from the designing stage and following with the management of waste generated on site, up to waste disposal. During a SWOT analysis of a successful construction waste management in the city of Shenzhen, China, Yuan (2012b) determines 'poor construction waste reduction' as a weakness. According to Yuan (2012b) the reason for a low overall level of construction waste reduction in Shenzhen is that at the project design stage, most of architects are not aware of the importance of construction waste reduction, which results in significant design changes in subsequent construction processes. In the goal of turning the weaknesses of this analysis into strengths, Yuan suggests to implement construction waste management throughout the whole life cycle of the project thus beginning with the design stage.

\section{Waste management methods used}

Waste generation during construction seems to be almost inevitable. If it is not avoided during the design stage (before construction begins) it should be managed after construction. Methods and models used worldwide for the management of construction waste are based in the same procedure. These known and mostly used procedures have four common steps to follow: reduce, reuse, recycle and dispose. The 3Rs, as the main strategies and steps in this hierarchy model begin with minimizing waste generation while reducing waste transportation, disposal and recycling costs (Esin and Cosgun, 2007). The reduction strategy is considered the most effective in minimizing waste generation.

However, as waste is unavoidable, after reduce, next in line come reuse and recycle strategies (Yuan and Shen, 2011). Reuse, as the second best option means the reuse of waste materials in construction more than once, either for the same function or for a different function. According to Peng et al., (1997) reuse is the most desirable option due to minimum processing and energy use needed. The third and last of the R's is recycling. Recycling is the use of waste materials (for a new or same function) after processing. Even though recycling needs material processing, it still saves a lot of new resources, transportation and production energy, and puts waste materials to use (Yuan and Shen, 2011). Figure 1 below shows the hierarchy model by Yuan and Shen (2011), and it is similar to other models used for construction waste management.

Figure 1 - The Construction waste management method hierarchy Source: Yuan and Shen (2011)

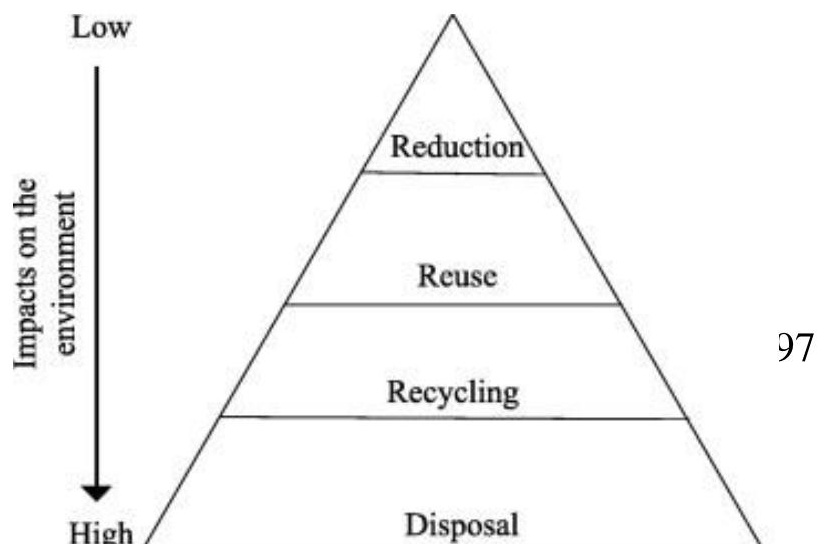


Other methods have pretty much the same steps and strategies in their models. In a specific case of a model found, one of the steps is also 'avoid' and as a first of the steps it is related more to the design stage but also to the construction stage. The best way to reduce waste generation during construction is to avoid generating any waste, what can be reached through better design and construction management. This same method, also shown in Figure 2 , has also 'treat' as a strategy. This step is related to the waste that is meant for disposing, and it is a strategy which encourages the treatment and the sorting of the mixed construction waste to be disposed. Dispose is the final step in all of these methods and models and it is the least desirable step. It does include the disposing of construction waste into landfills, which takes not only landfill space, but also energy to transport and all of this costs' a lot to the construction industry, but moreover it is environmentally unfriendly and hazardous. The above mentioned methods have ranked disposal as having the highest impact on the environment, or the lowest desirability.

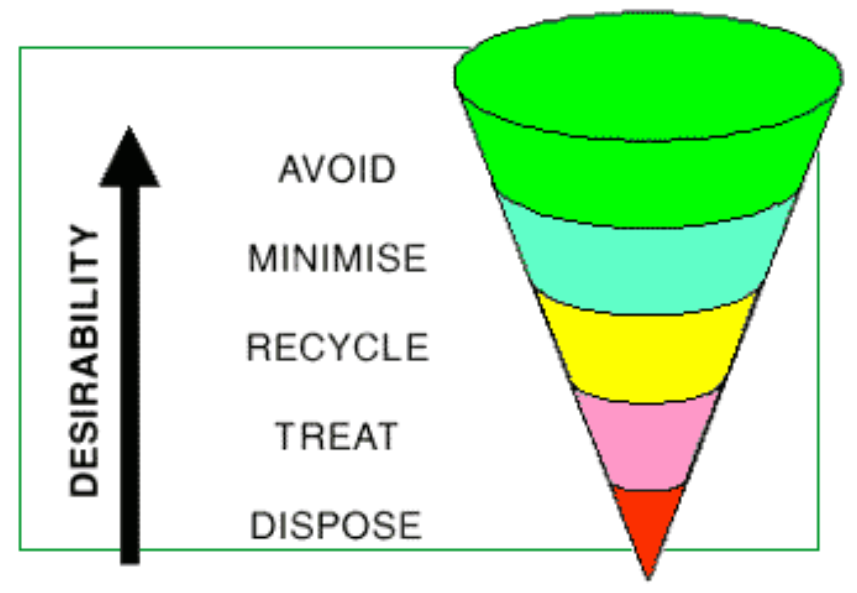

Figure 2 - The Construction waste management strategy Source: http://www.epd.gov.hk/epd/misc/cdm/management intro.htm

\subsection{Do these methods work?}

With all these well-developed models at hand, it is more than safe to assume that the future of waste management looks promising. However, the implementation of these methods in practice is not quite that effective (Tam, 2008). As this paper has previously discussed the responsible factors for lack of waste management (cost being the most important factor), the following table (Table 2) shows the responsible bodies for it.

\begin{tabular}{|l|r|r|r|r|}
\hline $\begin{array}{l}\text { Willingness to } \\
\text { minimize waste }\end{array}$ & Contractor (\%) & Client (\%) & Designer (\%) & Government (\%) \\
\hline Yes & 26.3 & 18.4 & 21.1 & 78.9 \\
\hline Neutral & 57.9 & 55.3 & 47.3 & 15.8 \\
\hline No & 15.8 & 26.3 & 31.6 & 5.3 \\
\hline Total & 100.0 & 100.0 & 100.0 & 100.0 \\
\hline
\end{tabular}

Table 2 - Survey results on willingness to minimize waste generation Source: Tam (2008)

As shown in Table 2, the most willing participant, in practicing waste management methods, is the government, whereas the most unwilling are contractors, clients and designers. Another study by Yuan and Shen (2011) separates the participants of the waste management process into two groups. The first group is oriented toward minimizing the amount of construction waste generated and disposed and it is comprised of authorities, general public and NGOs. 
The second group, on the other hand, is oriented toward the benefit and profits of conducting construction waste, and is very less concerned about the environmental degradation due to construction waste. This group is comprised of project clients, designers and, contractors and subcontractors. The percentages shown on the above table are quite disturbing, considering the amount of degradation waste disposal causes to the environment.

This leads into believing that the awareness of the public, and most importantly of the construction industry, towards such environmental issues is dangerously low. In this respect, in addition to new legislation relating construction waste management, it is suggested to create possibilities in raising the awareness of the public on environmental is sues. In this case these suggested regulations should at the same time address the environmental performance of construction waste management and its economical performance. The aim of such regulations is not only to increase the benefits of all involved parties, and this way promote and encourage construction waste management, but also increase their awareness toward its importance.

\section{Conclusion}

Construction waste makes up the highest percentage of total waste generated, and it is a big issue not only to the construction industry but to the general public as well, in the environmental aspect. This paper discussed construction waste management, methods used for this process and the difficulties encountered during their implementation. Cost seems to be the toughest challenge when it comes to construction was te management. Contractors, clients and designers are not highly encouraged to practice waste management if they do not find it beneficial or profitable. Furthermore, they benefit from not conducting construction waste management methods, as these are costly procedures, and by not conducting them the short-time investment cost decreases, therefore they get awarded projects. As for the environmental issues, it appears they are not a priority in the construction industry, if not profitable. There have been some suggestions made throughout this paper, and are mostly related to policy and legislation changes or additions, in order to encourage construction waste management among contractors, clients and designers, or the unwilling participants of the waste management process.

The existing orthodoxy for not conducting construction waste management methods, is that at times it is very easy to dispose any construction waste generated in unauthorized dump sites, and therefore, contractors and other participants in this process are discouraged to pay the additional cost of waste management which leads to ineffectiveness of the construction waste management methods.

This paper is limited to the discussion of only construction waste, although it is known that demolition has a big part in the waste generation process and at most times they are considered at the same time and as one. This limitation is mainly due to a general approach towards waste management methods during construction. Limited to a wide and a general discussion of waste management, this paper lacks discussion and analysis of construction waste for a specific area, country or city for a rather deeper analysis.

Due to the limitations in this paper, there is lack of analysis and comparison of construction and demolition waste management strategies and their effectiveness in different countries, especially developed countries in Europe or USA, as the highest waste generators. Therefore I suggest further research and a comparis on of different methods used for construction and demolition waste management and their effectiveness in developed countries. 


\section{References}

Begum, R \& Siwar, C (2007). Implementation of waste management and minimisation in the construction industry of Malaysia. 51 (1) p190-202

Environmental Protection Department (2009) Environmental Protection Department of the Government of the Hong Kong Special Administrative Region,

Available: http://www.epd.gov.hk/epd/misc/cdm/management intro.htm Last accessed:20th December, 2011

Esin, T \& Cosgun, N (2007). A study conducted to reduce construction waste generation in Turkey. Building and Environment. 42 p1667-1674

Karavezyris, V (2007). Treatment of commercial, construction and demolition waste in North Rthine-Westphalia: policy-making and operation options. Waste Management, 25 (2) (2007), p183-189

Lauritzen, E (1998). Emergency construction waste management. Safety Science. 30 (1) p43-53

March, C (2009). Operations management for construction. Oxon: Spon Press.

Melo, A \& Gonçalves, A (2011). Construction and demolition waste generation and management in Lisbon (Portugal). 55 (12) p1252-1264

Peng, C \& Domenic, S (1997). Strategies for successful construction and demolition waste recycling operations. Construction Management and Economics. 15 (1) p49-58

Poon, C (2007). Management of construction and demolition waste. Waste Management. 27 (2) p59-60

Tam, V (2008). On the effectiveness in implementing a waste-management-plan method in construction. Waste Management. 28 (6) p1072-1080

Yuan, H (2012a). Key indicators for assessing the effectiveness of waste management in construction projects. Ecological Indicators. 24 p476-484

Yuan, H (2012b). A SWOT analysis of successful construction waste management. Journal of Cleaner Production. 39 p1-8

Yuan, H \& Shen, L (2011). Trend of the research on construction and demolition waste management. 31 (4) p670679 